\title{
Mechanical properties of papercrete
}

\author{
Harith Zaki ${ }^{1, *}$, Iqbal Gorgis ${ }^{1}$ and Shakir Salih ${ }^{1}$ \\ ${ }^{1}$ Building and Construction Engineering Department, University of Technology, Baghdad, Iraq
}

\begin{abstract}
This paper studies the uses, of waste paper as an additional material in concrete mixes. Papercrete is a term as the name seems, to imply a mixture of paper and concrete. It is a new, composite material using waste paper, as a partial addition of Portland cement, and is a sustainable, building material due to, reduced amount of waste paper being put to use. It gains, latent strength due to presence of hydrogen bonds in microstructure of paper. Papercrete has been, reported to be a low cost alternative, building construction, material and has, good sound absorption, and thermal insulation; to be a lightweight and fireresistant material. The percent of waste paper used (after treating) namely $(5 \%, 10 \%, 15 \%$ and $20 \%)$ by weight of cement to explore the mechanical properties of the mixes (compressive strength, splitting tensile strength, flexural strength, density), as compared with references mixes, it was found that fresh properties affected significantly by increasing the waste paper content. The compressive strength, splitting tensile strength, flexural strength and density got decreased with increase in the percentage of paper.
\end{abstract}

\section{Introduction}

The world has been faced, with environmental problems such as global warming, forest destruction and lack of resources. Recycling of resources help solve, these environmental problems. Principally, paper; is one of the most effective recycling, resources to prevent global warming. According to Resource; Information System Incorporated (RISI), paper recycling is being done to the extent of about $60 \% \sim 80 \%$ in many countries, See Table $1[1]$. Waste management refers to awareness regarding the collection, transport, treatment, recycling and storage, of waste. The term usually refers to materials resulting from human activities and to the reduction; of their effect on the people's health, the environment, or the aspect of a habitat. Waste management may also contribute to saving natural; resources through the reuse of recoverable parts [2].

Waste paper has been used as building materials for decades, especially in cementitious; matrices, and since then a lot of research has been conducted to develop; the mechanical properties of the composite like; compressive, tensile, flexural strength, and etc. [3].

Use of wastepaper in structural concrete could; become economical and environment friendly, which helps to minimize harmful effects of construction process [4 \&5]. Paper is the most frequent; type of waste found in all activity areas and exemplifies an important source of cellulous fibers. In different forms (quality paper, mixed paper, newspapers and journals) paper exemplifies about $41 \%$ of all household waste produced today. Paper is a recyclable material; that after reaching the garbage dumps; has a biodegradation period of 3-12

* Corresponding author: almasrafharith@gmail.com months. That is why the benefits for nature through paper waste recycling are very important. Paper can be recycled in the technological flow; that has produced it for the manufacture of paper or the produce of cardboard and pasteboard. Paper can only be recycled 6-10 times, because with each recycling, the length of cellulose fiber is minimized, resulting in a decrease of the mechanical strength and quality (appearance, color) of the manufactured paper and an increase of technological losses.

Table 1. Recycling ratio of paper in some countries [1]

\begin{tabular}{|l|c|c|c|c|c|}
\hline & Korea & Japan & China & Taiwan & HongKong \\
\hline $\begin{array}{l}\text { Recycling } \\
\text { Ratio (\%) }\end{array}$ & 75.4 & 72 & 34 & 68 & 80 \\
\hline & U.S.A & Canada & Germany & U.K & France \\
\hline $\begin{array}{l}\text { Recycling } \\
\text { Ratio (\%) }\end{array}$ & 52 & 68 & 75 & 65 & 64 \\
\hline
\end{tabular}

Cellulose fiber; insulation uses recycled newspaper as a raw material, from which raw fibers are extracted and subsequently treated with special additives for fire proofing, as well as for preservation against pests. The manufacturing technology includes the application by injection of cellulose fibers. It can be applied for thermal insulation; of walls, floors, as well ceilings and roofs and also good sound insulation [2]. More than 450 million; tons of paper is generated worldwide per annum and it is predict that the demand for paper will extent to 500 million tons per annum by the end of 2020 [6].

Papercrete was produced by blending sufficient amount of waste paper with Portland cement type I, 
water and aggregate, and then slump and strength values were compared with those of conventional concrete. The slump minimized when a higher amount of paper; pulp content is added to concrete. The slump increased up-to $5 \%$ replacement by weight of cement, above $5 \%$ the slump minimized as the paper pulp content in the concrete mixtures increased. Many factors are accountable for adverse effects on the workability of paper pulp; concrete such as amount of paper pulp replacement, paper pulp physical properties and the carbon content of the paper pulp would be the central reasons for the lowering of concrete workability. The spotted compressive, splitting tensile and flexural strength raised up to $10 \%$ addition of waste paper pulp and further increase in waste paper pulp minimizes the strengths progressively. So the most appropriate mix proportion was using 5 to $10 \%$ replacement of waste paper pulp by weight of cement [7].

Paper is fundamentally wood cellulose, which is considered a fibrous' material. Cellulose is the second most generous material on earth after rock. Cellulose is a natural polymer, a long chain of associated sugar molecules made by the associating of smaller molecules. The links in the cellulose chain are a type of sugar: B-Dglucose. The cellulose chain bristles with polar-OH groups. These groups compose many hydrogen bonds with $\mathrm{OH}$ groups on approaching chains, bundling the chains together Fig. 1. The chains also pack orderly in places to form hard, stable crystalline regions that allow the bundled chains even more balance and strength. This hydrogen bonding produces the basis of papercrete strength [8]. The raw dry paper sludge includes silica and calcium oxide, followed by alumina and magnesium oxide. Cement blended with $10 \%$ and $20 \%$ calcined paper display a smaller reduction in compressive strength than the control cement [9].

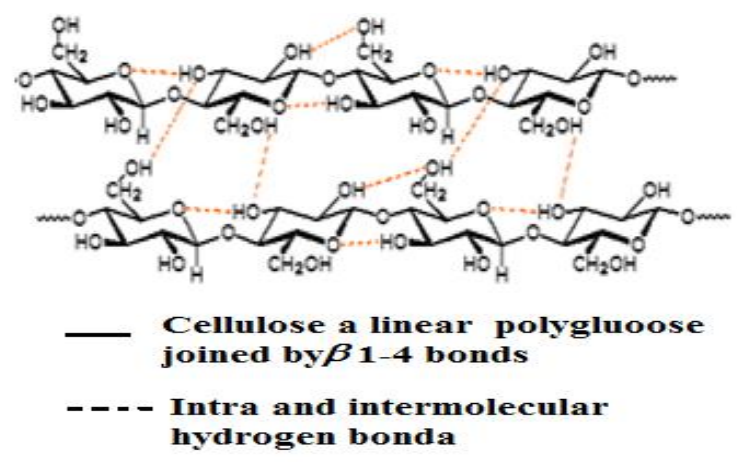

Fig. 1. Chemical structure of paper (Cellulose hydrogen bond $)^{[10]}$.

Papercrete is a complex material made of Portland cement, waste paper, water and/or sand. Papercrete has been reported to be a cheap alternative building material; to have good sound absorption and thermal insulation; to be a light weighted and fire- resistant material. It should be noted that papercrete is a relatively new concept with limited scope. Papercrete is famous by alternative names such as fibrous concrete, Padobe and Fidobe [11].
This paper summarizes the behavior of concrete with the waste paper pulp by adding cement in the range of $5 \%, 10 \%, 15 \%$ and $20 \%$ which may help to minimize the disposal problem of sludge and reinforce the properties of concrete.

The different objectives of the study of Papercrete are: -

- Study the properties of Papercrete to define its potential as a sustainable building material.

- Limit the Ideal Papercrete Mix.

- Formulate the samples of the locally available materials.

- Determine the strengths of various Papercrete mixes.

- Do prorated analysis of Concrete and Papercrete.

\section{Materials and properties}

\subsection{Cement}

Ordinary Portland cement (Type I) manufactured by (Lafarge company/ Bazian) commercially known as (Krasta) was used throughout the work. The physical properties are, given in Table 2, whereas the chemical composition and main compounds of cement are explained in Table 3. The test results of cement present that the cement conforms to Iraqi Specification No.5/1984 [12]. Tests were carried out by National Center for Construction Laboratories and Researches (NCCLR).

\subsection{Fine aggregate}

Al-Ekhaider natural sand was used as fine aggregate throughout the experimental work. Table 4 and Fig. 2 present physical and chemical properties of it. The test results were presented the gradation of the sand lies in zone [2] and the sulfate content $(0.37 \%)$ which are within the requirements of the Iraqi specification No. 45/ (1984) [13]. The tests were conducted at the Construction Materials Laboratory at Civil Engineering Department at University of Technology.

\subsection{Coarse aggregate}

Al-Soddor crushed coarse aggregate was used as coarse aggregate through the experimental work. It was tested to determine the sieve analysis as shown in Table 5 and Fig. 3 Also physical and chemical properties of gravel. The test results presented the gradation of the gravel and the sulfate content which are within the requirements of the Iraqi specification No. 45/ (1984) [13].

\subsection{Waste papers}

Waste paper used in this study was collected from schools, administration offices and libraries. The physical properties of the waste paper are shown in Table 6 . The papers were cut into small pieces by using 
paper cutter as shown in Fig. 4. These small dimensions prevent the paper from clumping when waste paper is assorted with water so the paper expands evenly in the papercrete mix. The paper was then soaked in water for three days Fig. 5 and then the paper sludge was placed on non- absorbent plate for squeezing out extra water content, after that the paper is subjected to grinding by using kitchen blender to obtain the required size of paper sludge. The paper sludge was collected from the grinder and stored for casting of papercrete specimens. Fig. 6 shows the paper mass after grinding in the wet grinder.

\subsection{Water}

Water is an important ingredient of papercrete as it is contributory in the chemical reaction with cement. Potable water should be used for both soaking and mixing of papercrete. It should be free from organic matter and the $\mathrm{pH}$ value should be between 6 and 7 .

Table 2. Physical properties of cement

\begin{tabular}{|c|c|c|}
\hline Physical Properties & $\begin{array}{c}\text { Test } \\
\text { results }\end{array}$ & $\begin{array}{l}\text { Limits of Iraqi } \\
\text { specification } \\
\text { No.5/1984 (12) }\end{array}$ \\
\hline $\begin{array}{c}\text { Fineness (Blaine method), } \\
\left(\mathrm{cm}^{2} / \mathrm{gm}\right)\end{array}$ & 3760 & $\geq 2300 \mathrm{~cm}^{2} / \mathrm{gm}$ \\
\hline $\begin{array}{l}\text { Setting time (Vicate } \\
\text { apparatus), } \\
\text { a. Initial setting, hrs:min } \\
\text { b. Final setting, hrs:min }\end{array}$ & $\begin{array}{l}2: 05 \\
4: 00\end{array}$ & $\begin{array}{l}\geq 45 \mathrm{~min} \\
\leq 10 \mathrm{hrs}\end{array}$ \\
\hline $\begin{array}{c}\text { Compressive strength, MPa } \\
\text { For } 3 \text { days } \\
\text { For } 7 \text { days }\end{array}$ & $\begin{array}{l}20.0 \\
25.0\end{array}$ & $\begin{array}{l}\geq 15 \mathrm{MPa} \\
\geq 23 \mathrm{MPa}\end{array}$ \\
\hline $\begin{array}{c}\text { Soundness Autoclave } \\
\text { method } \%\end{array}$ & 0.12 & $<0.8$ \\
\hline
\end{tabular}

Table 3. Chemical composition and main compounds of cement

\begin{tabular}{|c|c|c|}
\hline Oxides Composition & $\begin{array}{c}\text { Composition } \\
\text { Content \% }\end{array}$ & $\begin{array}{c}\text { Limits of Iraqi } \\
\text { specification No.5/1984 }\end{array}$ \\
\hline Lime, $\mathrm{CaO}$ & 66.11 & - \\
\hline Silica, $\mathrm{SiO}_{2}$ & 21.93 & - \\
\hline Alumina, $\mathrm{Al}_{2} \mathrm{O}_{3}$ & 4.98 & - \\
\hline Iron oxide, $\mathrm{Fe}_{2} \mathrm{O}_{3}$ & 3.10 & - \\
\hline Magnesia, $\mathrm{MgO}$ & 2.00 & $5.0 \% \operatorname{Max}$ \\
\hline Sulfate, $\mathrm{SO}_{3}$ & 2.25 & $2.8 \% \operatorname{Max}$ \\
\hline $\begin{array}{c}\text { Loss on Ignition, } \\
(\text { L.O.I. })\end{array}$ & 2.39 & $4.0 \% \operatorname{Max}$ \\
\hline $\begin{array}{c}\text { Insoluble residue, } \\
(I . R)\end{array}$ & 1.29 & $1.5 \% \operatorname{Max}$ \\
\hline $\begin{array}{l}\text { Lime Saturation } \\
\text { Factor, (L.S.F.) }\end{array}$ & 0.93 & $0.66-1.02 \%$ \\
\hline \multicolumn{3}{|c|}{ Main compounds (Bogues equations) } \\
\hline$C_{3} S$ & 58.16 & - \\
\hline$C_{2} S$ & 19.00 & - \\
\hline$C_{3} A$ & 7.95 & $>5 \%$ \\
\hline$C_{4} A F$ & 9.43 & - \\
\hline
\end{tabular}

Table 4. Properties of fine aggregate

\begin{tabular}{|c|c|c|}
\hline $\begin{array}{c}\text { Sieve size } \\
(\mathrm{mm})\end{array}$ & $\begin{array}{c}\text { Passing by } \\
\text { weight } \%\end{array}$ & $\begin{array}{c}\text { Limits of IQS } \\
\text { (No.45/1984) } \\
\text { Zone (2) [13] }\end{array}$ \\
\hline 9.51 & 100 & 100 \\
\hline 4.75 & 98 & $90-100$ \\
\hline 2.36 & 89 & $75-100$ \\
\hline 1.18 & 77 & $55-90$ \\
\hline 0.6 & 55 & $35-59$ \\
\hline 0.3 & 21 & $8-30$ \\
\hline 0.15 & 5 & $0-10$ \\
\hline \multicolumn{2}{|c|}{ Fineness Modulus $=2.8$} \\
\hline Property & Test Results & $\begin{array}{c}\text { Limits of IQS } \\
\text { No.45/1984) (13) }\end{array}$ \\
\hline Specific gravity & 2.6 & - \\
\hline $\begin{array}{c}\text { Bulk Density } \\
(\text { kg/m3) }\end{array}$ & 1712 & - \\
\hline Sulfate content $\%$ & 0.37 & $\leq 0.5$ \\
\hline Absorption\% & 3.2 & - \\
\hline
\end{tabular}

Table 5. Properties of coarse aggregate.

\begin{tabular}{|c|c|c|}
\hline Sieve size (mm) & $\begin{array}{c}\text { Passing by } \\
\text { weight } \%\end{array}$ & $\begin{array}{c}\text { Limits of IQS } \\
\text { (No.45/1984)(13) }\end{array}$ \\
\hline 20 & 100 & $95-100$ \\
\hline 14 & - & - \\
\hline 10 & 42 & $30-60$ \\
\hline 5 & 3 & $0-10$ \\
\hline Property & Test Results & $\begin{array}{c}\text { Limits of } \\
\text { (IQSNo.45/1984)(13) }\end{array}$ \\
\hline Specific gravity & 2.68 & - \\
\hline $\begin{array}{c}\text { Bulk Density } \\
(\mathrm{kg} / \mathrm{m} 3)\end{array}$ & 1712 & - \\
\hline Sulfate content\% & 0.098 & $\leq 0.1$ \\
\hline Gypsum \% & 0.210 & $\leq 0.215$ \\
\hline Fine material \% & 0.56 & $\leq 3$ \\
\hline Absorption \% & 0.43 & - \\
\hline
\end{tabular}

Table 6. Physical properties of waste paper.

\begin{tabular}{|c|c|}
\hline Moisture Content \% & 2.67 \\
\hline Specific Gravity ( SSD) & 0.98 \\
\hline Density $\left(\mathrm{kg} / \mathrm{m}^{3}\right)$ & 800 \\
\hline Absorption \% & 89 \\
\hline Organic Materials \% & 70 \\
\hline In-organic materials \% & 30 \\
\hline
\end{tabular}

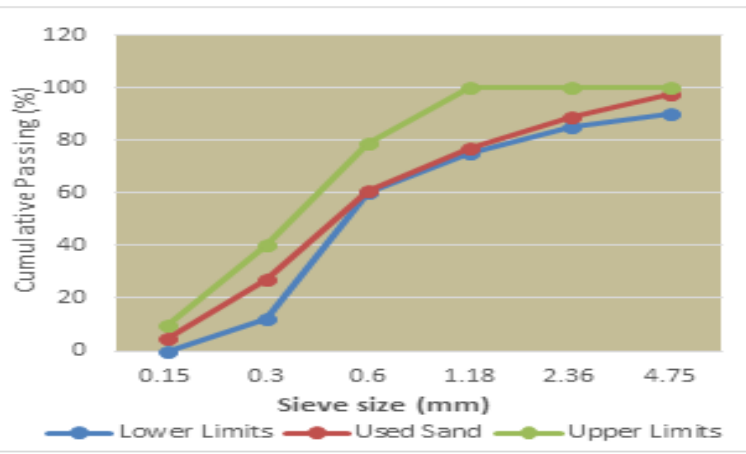

Fig. 2 . Grading curve for used fine aggregate. 


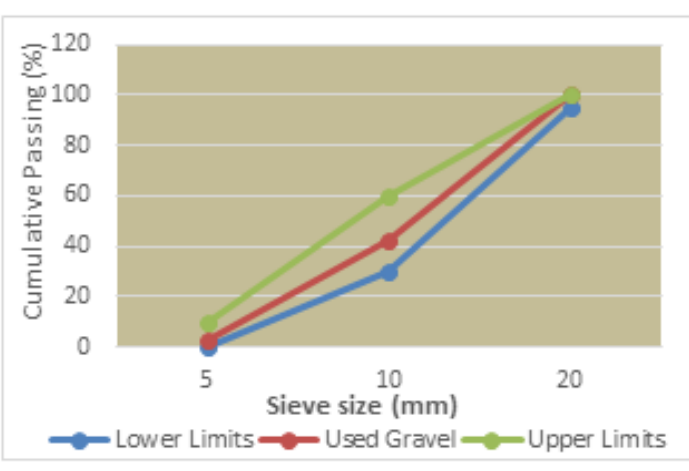

Fig. 3. Grading curve for used coarse aggregate.

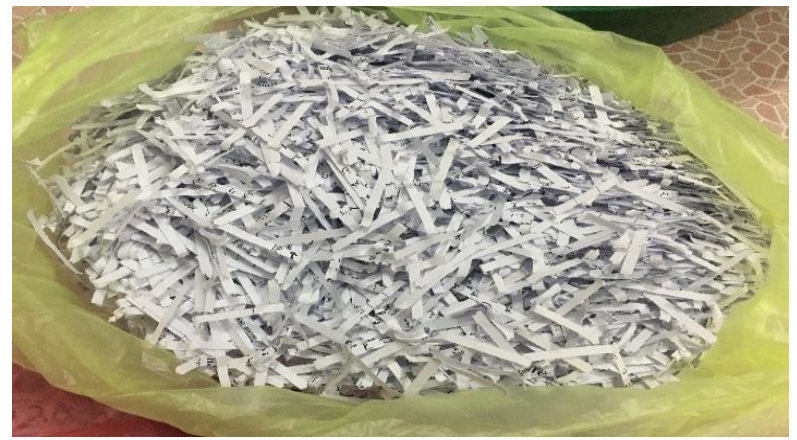

Fig. 4. Sample of paper shredder



Fig. 5. Paper pieces soaked in water
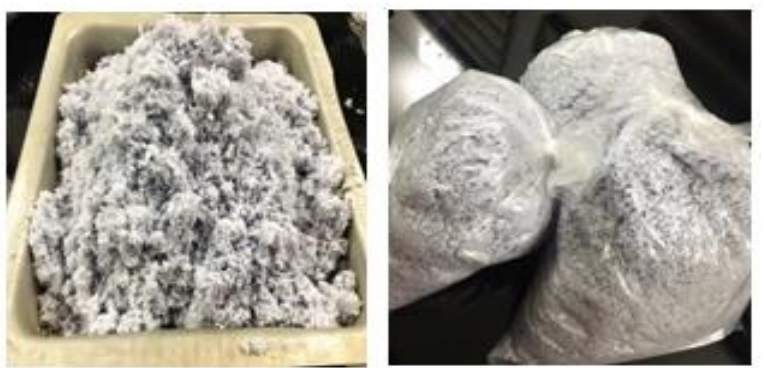

Fig. 6. Paper mass after soaked and grinding

\section{Experimental program and test procedures}

\subsection{Proportion of the mix.}

The mix proportion was designed to get approximately about $25 \mathrm{MPa}$ compressive strength of normal concrete. Trial mixes were prepared for workable mix while adding waste paper. At last the mix proportion by weight was [1:1.9:2.5] cement: fine aggregate: coarse aggregate, water cement ratio was kept constant as $\mathrm{w} / \mathrm{c}=$ 0.35 to keep the slump value the same by adding super plasticizer called Sika. The weight of cement, sand and gravel that were used in all mixes were $400(\mathrm{~kg} / \mathrm{m} 3), 760$ $(\mathrm{kg} / \mathrm{m} 3)$ and $1000(\mathrm{~kg} / \mathrm{m} 3)$ respectively. Four Papercrete mixes were then prepared by adding paper sludge by weight of cement as $5 \%, 10 \%, 15 \%$ and $20 \%$ as shown in Table 7.

\subsection{Fresh concrete test}

\subsubsection{Slump Test}

Workability is one of the important features defining the fresh properties of concrete and can be defined as a measure of the ability of concrete to be mixed, handled, transported and placed without loss in homogeneity and with less air voids. A slump test is a suitable test to determine the workability for all types of concrete mixes; the test was performed according to ASTM C143 [14].

\subsubsection{Fresh Density}

This test is conducted according to ASTM C567-05a [15]. The average of three cubes of (100) $\mathrm{mm}$ is considered to determine the fresh concrete density.

\subsection{Hardened Concrete Test}

- Density of hardened concrete is determined using air dried cubes of sizes $(100 \times 100 \times 100) \mathrm{mm}$ according to B.S 1881: part 114: 1989 [16]. The specimens were tested after picking the cubes out of the curing water after drying their surfaces by a piece of cloth. Density $(\rho)$ is the mass of a unit volume of hardened concrete expressed in kilograms per cubic meter.

- Compressive Strength was determined according to B.S 1881: part 116, 1989 [17]. The average compressive strength of three cube specimens was recorded. This test was conducted at 7, 28 and 60 days of age.

- Splitting Tensile Strength was done according to ASTM C496 - 07 [18] and the average splitting tensile strength of three specimens were recorded. This test was conducted at ages 7,28 , and 60 days.

- The modulus of rupture was determined by using $(100 \times 100 \times 400) \mathrm{mm}$ prism specimens; in conformity with ASTM C78 -04 [19] the prisms were subjected to two third point loading system. The loading was applied at a rate of $0.02 \mathrm{MPa} / \mathrm{sec}$, the specimens were tested at age of $(7,28$, and 60$)$ days. The average of two specimens in each age was adopted.

- Absorption test is determined using cubes of sizes (100x100x100) $\mathrm{mm}$ to define the absorption capacity in accordance with the ASTM C642-03 [20].

- Fire resistance test, papercrete cubes cured for 28 days and air-dried for 1 hour were burnt to a temperature of $800^{\circ} \mathrm{C}$ for 10 minutes in a furnace. The cubes were allowed to cool for 1 hour in the open air before the determination of their residual compressive strength. 


\section{Results and discussion}

\subsection{Fresh Concrete}

The slump test and fresh density results are explained in Table 7. Together slump and density decreased when a higher amount of paper pulp content was included. The as-received pulp presented a high water-absorption capability. Thus, when a higher amount of paper pulp was included in the mixture, it required more water to achieve a given slump. The workability of concrete containing paper-mill residual was improved by the addition of super-plasticizer to achieve good workability with reinforced strength of papercrete. While density decreased by the addition of paper. Several factors could lead to apposite effects on the workability and density of papercrete. The amount of paper pulp addition, paper pulp physical properties, and the carbon content of the paper pulp would be the main reasons for the reduction of concrete workability and density. The increase in water demand becomes larger with an increase in the paper pulp content to about $20 \%$.

Table 7. Results of slump and fresh density

\begin{tabular}{|c|c|c|c|c|}
\hline $\begin{array}{c}\text { Mix } \\
\text { ID }\end{array}$ & $\begin{array}{c}\text { \% of pulp } \\
\text { paper mass } \\
\text { by weight } \\
\text { of cement }\end{array}$ & $\begin{array}{c}\text { Admixture } \\
\text { (Sika) (\%) by } \\
\text { weight of } \\
\text { cement }\end{array}$ & $\begin{array}{c}\text { Slump } \\
(\mathrm{mm})\end{array}$ & $\begin{array}{c}\text { Fresh density } \\
\left(\mathrm{kg} / \mathrm{m}^{3}\right)\end{array}$ \\
\hline$R$ & 0 & 0.75 & 45 & 2445 \\
\hline M5 & 5 & 1 & 48 & 2469 \\
\hline M10 & 10 & 1.5 & 50 & 2203 \\
\hline M15 & 15 & 2.5 & 46 & 2183 \\
\hline M20 & 20 & 3 & 42 & 2135 \\
\hline
\end{tabular}

\subsection{Hardened concrete}

The dry density and water absorption test of the papercrete was done by using pulp paper and the results are shown in Table 8 and Fig. 7. It was noted that the bulk density and water absorption of the papercrete change inversely with the waste paper content of the mixtures. The water absorption of the cubes expanded with the expanding waste paper content. High measure of water ingestion is because of the nearness of cellulose materials that effectively assimilates water and holds it for long time. The average test results of splitting tensile strength, compressive strength and flexural strength done at 7, 28 and 60 days age are recorded in Tables 8 and 9. The test results demonstrated an expanding with curing age because of proceeding of hydration process. The compressive, splitting tensile and flexural strength of concrete blends with paper pulp were less than reference mixes for all test ages aside from the blend with $(5 \%)$ expansion of paper pulp by weight of cement. The results showed reduction when higher paper pulp contents were involved in the concrete mixes. Fig. 8 presents the compressive strengths of all 5 mixes at 7,28 and 60 days. The paper pulp content in the concrete mixtures performed a great role in the mechanical properties. Yet, as the paper mass content rises, the strength falls down.
The same trend was seen in Fig. 9 for splitting tensile strength. This is because of loss in cohesion and also the poor binding of calcium- hydrate - silicate (C-S-H) gel on cellulosic material. Besides adding waste paper will take part of concrete mix from the volume and any contraction will decrease the concrete mix which will debilitate the concrete. On the other hand the flexural strength results shown in Fig. 10, it can be seen that flexural strength of concrete mixes with paper pulp were as much as reference mixtures for all test ages. The fire resistance was depicted as a measure of the residual compressive strength of papercrete cured for 28 days, dried and subsequently subjected to heat at $1000^{\circ} \mathrm{C}$. The 28-day compressive strength result for papercrete cubes, before and after burning, is introduced in Fig. 11. There is a general lessening in their compressive strength after burning. The crevice between the compressive strength lines of the papercrete progressed toward becoming smaller with increase in waste paper content. This demonstrates that the fire resistance of papercrete increased with increase in waste paper content.

Table 8. Results of hardened concrete mixes properties

Table 8. Results of hardened concrete mixes properties
\begin{tabular}{|c|c|c|c|c|c|}
\hline $\begin{array}{c}\text { Mix } \\
\text { ID }\end{array}$ & $\begin{array}{c}\text { Dry } \\
\text { density } \\
\left(\mathrm{kg} / \mathrm{m}^{3}\right)\end{array}$ & $\begin{array}{c}\text { Water } \\
\text { absorption } \\
(\%)\end{array}$ & \multicolumn{3}{|c|}{$\begin{array}{c}\text { Compressive Strength } \\
(\mathrm{MPa})\end{array}$} \\
\cline { 5 - 6 } & & 7 days & 28 days & 56 days \\
\hline R & 2140 & 6.3 & 32.6 & 39.7 & 48.7 \\
\hline M 5 & 2159 & 5.9 & 33.2 & 42.1 & 49.9 \\
\hline M 10 & 2015 & 8.4 & 21.7 & 31.4 & 37.3 \\
\hline M 15 & 1989 & 12.4 & 17.4 & 22.2 & 26.9 \\
\hline M 20 & 1894 & 14.6 & 11.3 & 16.8 & 21.2 \\
\hline
\end{tabular}

TABLE 9. Average tensile strength of mixes.

TABLE 9. Average tensile strength of mixes.
\begin{tabular}{|c|c|c|c|c|c|c|}
\hline \multirow{2}{*}{$\begin{array}{c}\text { Mix } \\
\text { ID }\end{array}$} & \multicolumn{2}{|c|}{$\begin{array}{c}\text { Splitting Tensile } \\
\text { Strength (MPa) }\end{array}$} & $\begin{array}{c}\text { Flexural Strength } \\
\text { (MPa) }\end{array}$ \\
\cline { 2 - 7 } & $\begin{array}{c}7 \\
\text { days }\end{array}$ & $\begin{array}{c}28 \\
\text { days }\end{array}$ & $\begin{array}{c}56 \\
\text { days }\end{array}$ & $\begin{array}{c}7 \\
\text { days }\end{array}$ & $\begin{array}{c}28 \\
\text { days }\end{array}$ & $\begin{array}{c}56 \\
\text { days }\end{array}$ \\
\hline R & 2.5 & 3.3 & 3.5 & 4.4 & 5.5 & 5.8 \\
\hline M 5 & 2.7 & 3.5 & 3.6 & 4.3 & 5.4 & 5.7 \\
\hline M 10 & 2.2 & 2.8 & 3.3 & 3.4 & 4.4 & 4.8 \\
\hline M 15 & 1.8 & 2.4 & 2.7 & 3.2 & 4.1 & 4.3 \\
\hline M 20 & 1.5 & 1.9 & 2.4 & 2.4 & 3.4 & 3.6 \\
\hline
\end{tabular}




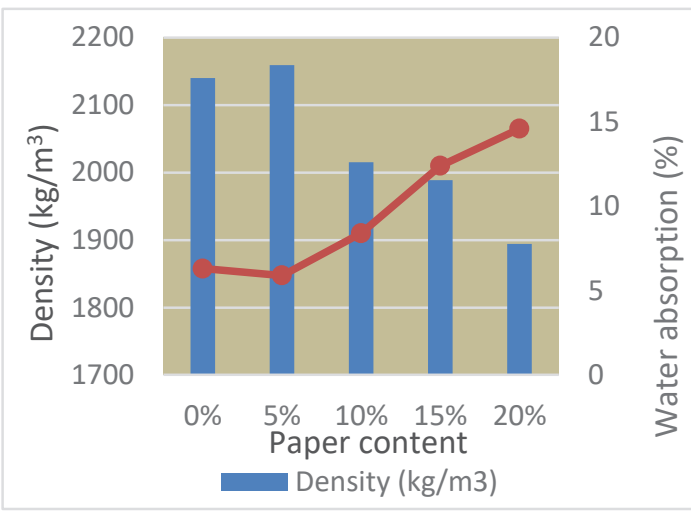

Fig. 7. Variation in density with water absorption



Fig. 8. Results of compressive strength of concrete

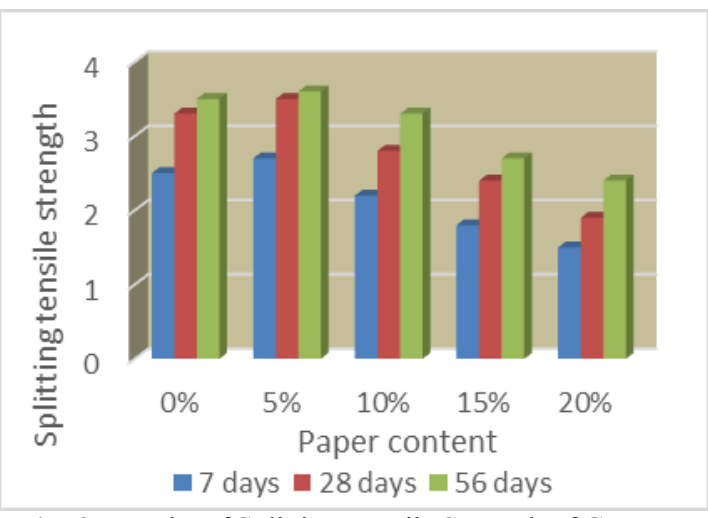

Fig. 9. Results of Splitting Tensile Strength of Concrete

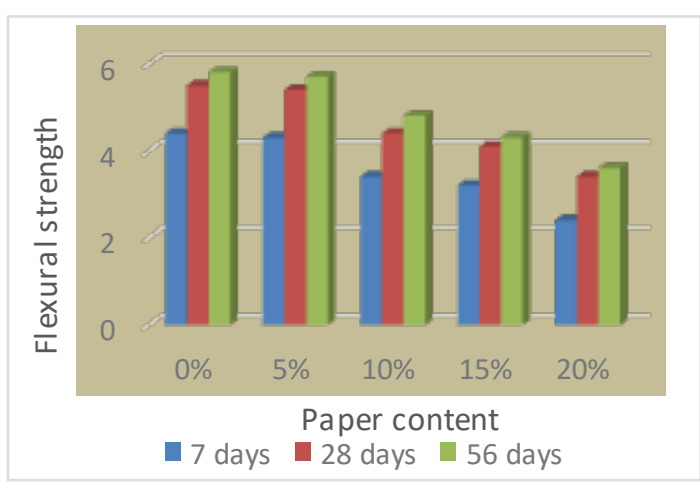

Fig. 10. Results of flexural strength of concrete.

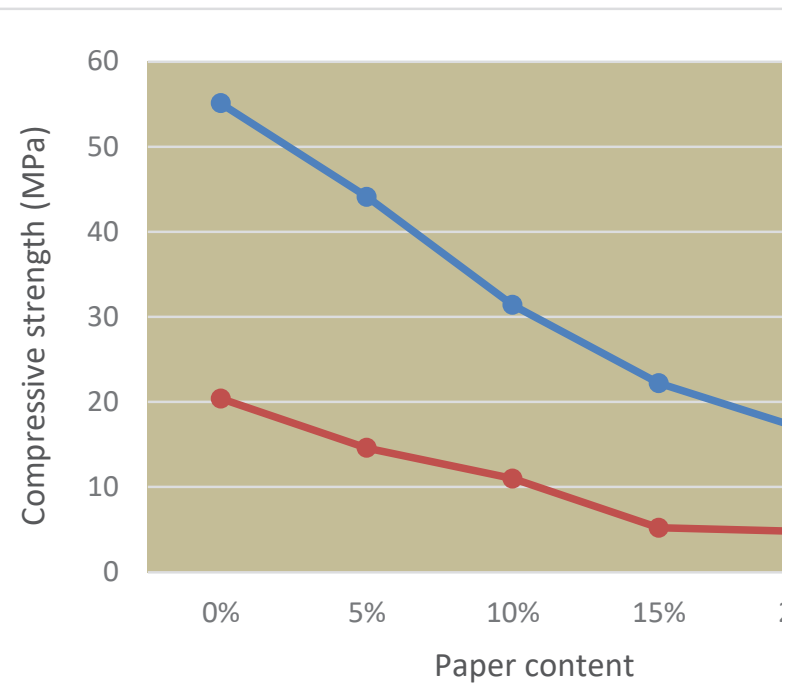

Fig. 11. Variation of 28-day compressive strength of papercrete (before and after burning)

\section{Conclusions}

Based on the experimental work results in this investigation, the following conclusions can be drawn:

1. The low bulk density of papercrete demonstrates that waste paper could be an important alternate sustainable material for production of light weight concrete.

2. The reuse of wastes is essential from various perspectives: It helps to save and sustain the natural resources which are not replenished; it decreases the pollution of the environment and it also helps to save and recycle energy in the production process. Additionally, suitable landfill sites are becoming more difficult to find as urban areas expand.

3. It has been confirmed that adding waste paper has a distinct antagonistic impact on the slump and fresh density. For which request higher water or higher chemical admixture dosages to keep the slump values as far as possible.

4. Adding waste paper to concrete mix prompted an increase in water absorption and a decrease in dry density for all mixes used aside from the mixture with $5 \%$ of paper pulp. The results of dry density demonstrate that lightweight concrete could be created by adding waste paper.

5. Results of compressive strength, and splitting tensile strength for $(10 \%, 15 \%$ and $20 \%)$ mixes decreased with the increase of the amount of wastepaper. While in the mixture with (5\%), the strength was higher than the reference since waste paper contains considerable amount of alumino-siliceous material that is combined with calcium, leading to the improvement in its strength. The advancement of this strength is predominantly inferable to the hydraulic and pozzolanic activity of waste paper that is activated by the alkalis and to some extent, $\mathrm{Ca}(\mathrm{OH})_{2}$ 
which is released from the hydration process. While results of flexural strength were less than reference mixes for all test ages.

6. Papercrete should not be utilized for external walls and near-ground walls due to its high water absorption capacity. If it has to be used for external walls, the surface of the walls must be waterproof.

7. The reductions in compressive strength of the papercrete cubes after burning were less than 1 $\mathrm{N} / \mathrm{mm}^{2}$. This might be ascribed to the thermal insulation of the interior of the burnt papercrete cubes.

8. The optimum percent of paper is $20 \%$ and can be utilized to produce bricks with light weight and good fire resistance.

\section{References}

1. J.H. Chung, B.H. Kim, H.k. Choi \& C.S. Choi, Int. Con. on S. B. 14, 317-318 (2015).

2. C. Aciu, D.A. Ilutiu, N. Cobirzan, \& A. Balog, Int. Con. Int. in Eng., 295-300 (2014).

3. R.S. Gallardo \& M.A. Adajar. Sym. on Inf. D. \& E. 2006, 7-8 (2006).

4. V.K. Vishwakarma, \& P.K. Patil, Int. J. for Sc. R. \& D. 4, 561 (2016).

5. J. Singh \& P.K. Patil, Int. J. for Sc. R. \& D. 4, 784 (2016).

6. A. Hashmi, H.N. \&, N. Baig, Int. J. of Eng. 11, 337-340 (2013).

7. S. F. Seyyedalipour, D. Y. Kebria, N. R. Malidarreh, \& G. Norouznejad, Int. J. of Eng. R. \& A. 4, 115122 (2014).

8. S. Khandelwal, K. L. Prajapat, M. Kumar, L. Bhantia, A. Sharma, V. Sharma, Int. J. of C. R. \& D. 4, 668 (2015).

9. I. Vegas, J. Urreta, M. Frías, \& R. García, C. \& B. M., 23(8) (2009).

10. G.V.S. Prasad, P.P. Reddy, M.Swathi, P.D.V.Kumar, T.Praveenraja, M.Naveen, In. J.of Eng. R., 3 (2015).

11. B J Fuller, AFafitis and J L Santamaria. ASCE Civil Engineering 75, 72 -77 (2006).

12. IQS. No.5-1984, "Portland cement", Iraqi Standard Organization, Central Organization for Standardization and Quality Control.

13. IQS. No. 45-1984," Aggregate from Natural Sources for Concrete", Iraqi Standard Organization, Central
Organization for Standardization and Quality Control.

14. ASTM C143, "Standard Test Method for Slump of Hydraulic Cement Concrete", 2000.

15. ASTM C567-05a, "Standard Test Methods for Determination Density of Structural Lightweight Concrete" ASTM International, Annual Book of ASTM Standards, American Society for Testing and Materials, 04.02, United States, 2006.

16. B.S.1881, Part 114, "Methods for Determination of Density of Hardened Concrete", British Standards Institution, 1983.

17. B.S 1881: Part 116, 'Method for Determination of Compressive Strength of Concrete Cubes", , British Standards Institution., 3, 1989.

18. ASTM C496/C496M, "Standard Test Method for Splitting Tensile of Cylindrical Concrete Specimens", Annual Book of ASTM standard, 04.02, 283-287 (2004).

19. ASTM C78-02.' 'Standard Test Method for Flexural Strength of Concrete", Annual Book of ASTM standard, 04.02 (2002).

20. ASTM C642-03a, "Standard Test Method for Density, Absorption, and Voids in Hardened Concrete", Annual Book of ASTM Standards, American Society for Testing and Materials, 04-02 (2003). 